\title{
藻場造成に伴うホッカイエビ生息条件の解明
}

\section{Habitable Wave Condition for Panadalus Kesseri}

\author{
瀬戸雅文 ${ }^{*}$. 姴井泉 ${ }^{*}$. 松岡学 ${ }^{* *}$ - 山下俊彦 ${ }^{* * *}$
}

Masabumi Seto,Izumi Sakurai,Gaku Matsuoka and Toshihiko Yamashita

The wave condition to develop the habitat for Panadalus Kesseri is determined by this experimental study. In this study its thrust force and fluid force in oscillatory flow are measured,and the habitable condition is estimated from the balance of them. Consequently, the maximum wave height $\mathrm{Hmax}$ is approximately $3.47 \times 10^{-2} \mathrm{BL}^{0.8} \mathrm{~d}^{0.5}$ on small amplitude wave theory. Where $\mathrm{BL}$ is body length of $P$.kesseri, $\mathrm{d}$ is water depth. Therefore, the wave height need to be restrained below Hmax, to develop an habitat of $P$. kesseri by using an algae zone.

Keywords : thrust force, fluid force, habitat

\section{1.はじめに}

ホッカイエビは東北地方以北のアマモ場やスカモ場内に広く生息する藻場性生物で、特に北海道東部の野付湾、 サロマ湖、能取湖沿岸では地元の風物詩として水産・観光価值の極めて高いエビである。ホッカイエビの生活史 や成長については柏木”、水島 ${ }^{2)}$ の研究などによって知見が収集され、本種が雌雄同体種で雄性先熟の性転換を 行うこと、毎年 9 月上旬〜 11月（生息地により限定される）に産卵後約 $6 〜 9$ ケ月間腹部に抱卵し、翌春水温が 10 ${ }^{\circ} \mathrm{C}$ 前後となる4〜6月下旬に幼生がほぼ100\%ふ出することなどが解っており、これら一連の生活史は体長（BL）に より図ー1のように整理されている。また、個体群の変動や構造などついては水島 ${ }^{3)}$ の研究があり、藻場が害敵 からの隠れ場、餌場として機能し、特に当歳群の主な减耗要因が魚類による食害であること、アマモ密度と幼稚 仔の生息密度に正の相関が認められることなどが解って いる。従って、ホッカイエビ生息場造成のための条件と しては、幼稚仔が落場内で能動的に行動し害敵よりの隐 れ場としての機能を積極的に利用できるための諸条件を 满足させることが考えられる。

本研究は、藻場海域における棵境造成技術の一環とし て、行動実験的手法及び水理実験的手法を用いてホッカ イエビの生息条件を波浪・流動環境下におけるエビの流 れ耐性面及びェビに作用する流体力よりエ学的に評価す ることによってホッカイエビ生息場造成を規定する流動

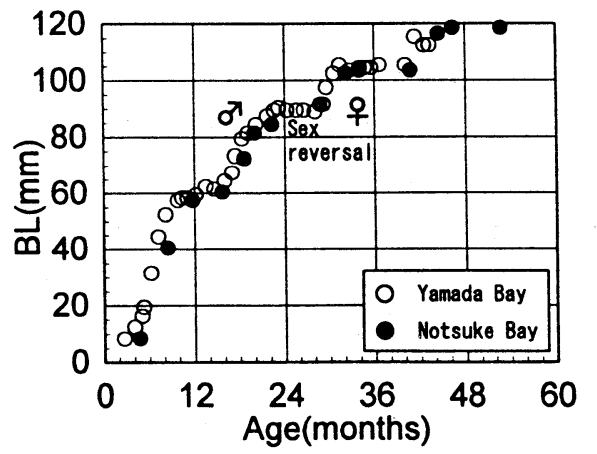

図ー1 ホッカイエビの体長による成長過程 ${ }^{112)}$

2. 解析理論

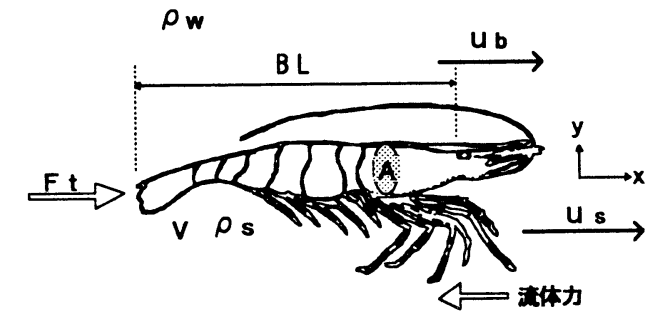

図ー2 エビ周辺のカの验合い
図ー 2 に示すように水平流速 ubに対して流れ方向に速度 usで 遊泳するホッカイエビに関する運動方程式は（1）式のように表現

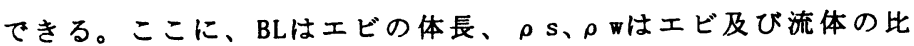
重、Vはエビの排除水質量、Aはエビの流れ方向の射影面積、 $\mathrm{F}$ tはエビの推力、更に $\mathrm{C}$ 力及び $\mathrm{C}$ Mは抗力係数及び質量力係数で 遊泳中であることから底面摩擦の影響は無視する。なお、ホッカ イエビの遊泳運動の様式は腹肢の規則的な運動による正の走流 （推進）行動と害敵等より逃避する場合に行われる尾扇の断続的

* 正会員 北海道立中央水産試験場 水産工学室 (046 北海道余市郡余市町浜中町 238)

** 学生会員北海道大学大学院

*** 正会員北海道大学工学部土木工学科 


$$
\rho s V \frac{d u s}{d t}=\rho w V \frac{d u b}{d t}-C_{M} \rho V \frac{d}{d t}(u s-u b)-\frac{1}{2} C_{D} \rho w A|u s-u b|(u s-u b)+F t
$$

な跳飛び行動に分類されるが、本研究ではエビが能動的に 遊泳方向を選択可能な正の走流行動について考察する。 図ー3は実験に使用したホッカイエビの射影面積 A（本 実験では简便のためにエビの第 4 歩脚より体軸と垂直な基 部断面稖と定義する）及び排除水質量 Vの体長BLによる変 化を両対数で示したものである。図中の実線は両対数で傾 き 2 及び3の直線であるが、これより射影面積及び排除水質 量は体長の2乗及び3乗にほほ比例して変化しており、それ ぞれ次式で近似できることがわかる。

$$
\begin{array}{ll}
\mathrm{A}=1.78 \times 10^{-2} \mathrm{BL}^{2} & \left(\mathrm{~cm}^{2}\right) \\
\mathrm{V}=1.29 \times 10^{-2} \mathrm{BL}^{3} & \left(\mathrm{~cm}^{3}\right)
\end{array}
$$

また、今回実験に使用したェビの比重は、体長によらず ほほ一定で

$$
\rho s=1.080
$$

であった。なお、（1）式は、 $\mathrm{u} \mathrm{s}=0 、 \mathrm{~d} \mathrm{ub} / \mathrm{d} t=0$ の場 合には

$$
\mathrm{Ft}=-\frac{1}{2} \mathrm{C}_{\mathrm{D} \rho} \mathrm{wA}|\mathrm{ub}| \mathrm{ub}
$$

となり、定常流速值とエビの遊泳速度が验合う場合の $\mathrm{ub}$ 值と $\mathrm{C}$ 值より推力 $\mathrm{F} t$ を計算できる。

\section{3. 実酸方法}

\section{3-1. 流動耐性実験}

ホッカイエビの流動耐性実験には、1995年10月16日北海 道東部の網走市能取湖内でソリネットによって採取された 当歳エビ $(B L=41 \sim 43 \mathrm{~mm}) 、 1$ 歳エビ $(B L=65 \sim 72 \mathrm{~mm})$ 及び 2 歳エ ビ $(B L=85 \sim 91 \mathrm{~mm})$ を各 3 匹使用し、図ー 4 に示す実験概要で 実施した。

ホッカイエビは保讙色（アマモなどの藻類における緑棍 色）に類似し、かつ低照度の器境をより好む傾向が飼育中 琶められたため、実験ではこの性質を利用した。すなわち 水路（水路幅 $30 \mathrm{~cm}$ 、水深 $35 \mathrm{~cm}$ ）内の上流側より $60 \mathrm{~cm}$ の区間 （側壁及び底面）を黒色に塗装し、上部をカーテン等で遮 光した上で残りの $90 \mathrm{~cm}$ の区間を水槽上部より 300 叭のロ ゲ ンライトで照明することにより水路内に照度の勾配を形成 することによってェビの遊泳方向（正の走流性）を制御し た。実験に先立ち、予め水路内を $13^{\circ} \mathrm{C}$ (エビを採取した能 取湖浅海域の10月の水温に相当)に調温した上で実験に使 用するエビを入れ、十分行動が安定した後に主流流速值を

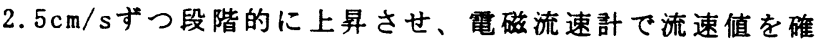
認しながら水路内のエビの遊泳行動をビテオテープに収録 し画像解析することによって成長段階別のエビの最大遊泳 速度を解析した。

本実験に使用した水槽全体図を図一 5 に示す。本水槽は 海水対応（主要材料SUS316製）で水温調節機能、淢過機能 を備えた重直循㻴式の小型回流・振動流水椤（水路カララ
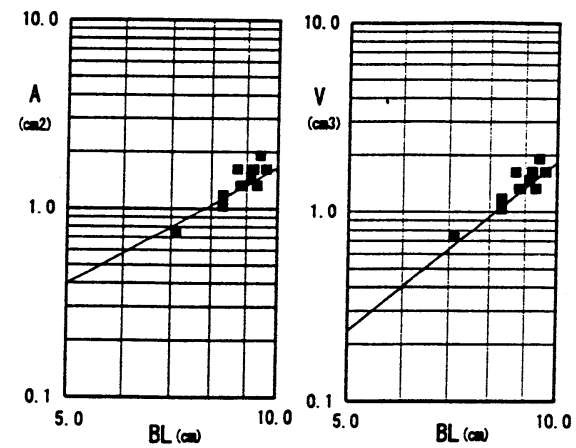

図ー3エビの射影面積及び排除水質量

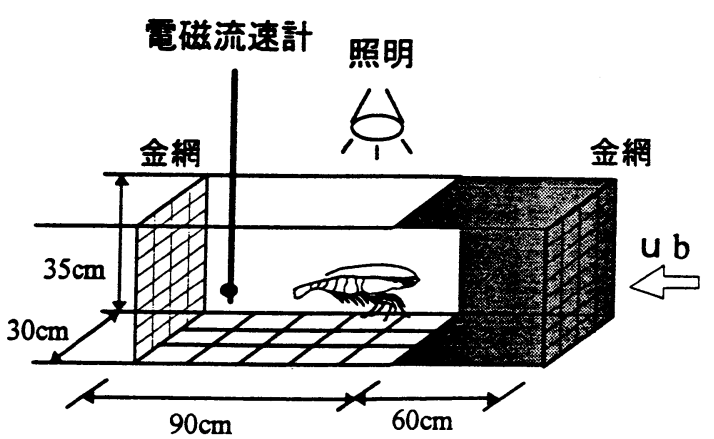

図一 4 流動耐性実験図

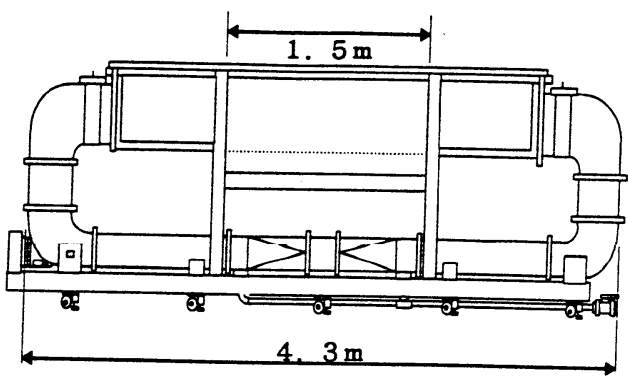

図 -5 実験水槽

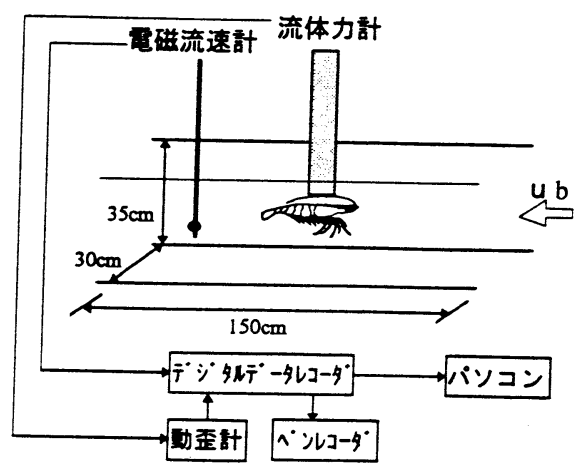

図一 6 流体力測定概念図 
部全長 $3.5 \mathrm{~m}$ 、観測部水路長 $1.5 \mathrm{~m}$ 、水路幅 $30 \mathrm{~cm}$ 、水深 $35 \mathrm{~cm}$ 、 標準水容量 700L、ジャヘ・ンアクアテック社製）で、循㻴管路下側の 中心に配置されたインペラの回転をパンコンで制御するこ とによって流速約 $-100 \mathrm{~cm} / \mathrm{s} \sim 100 \mathrm{~cm} / \mathrm{s}$ の籁曲で任意の非定 常流（定常流、振動流含）を発生させることができる。

\section{3-2. 流体力測定実酫}

ホッカイエビに作用する流体力測定実験の概要図を図一 6 に示す。実験では5\%浱度のホルマリンで遊永形状に固定 したホッカイエビを微小流体カ測定用に試作した小型二分 力計 $(1 \mathrm{~g}$ 単位で検定) に設置し、小型回流・振動流水槽を 用いて定常流 $(0 \sim 105 \mathrm{~cm} / \mathrm{s})$ 及び振動流（周期4 8秒）場にお ける作用流体力を動歪み計を通して計測し、電磁流速計に よる主流流速值と共に何れも $50 \mathrm{~Hz}$ でA/D変換後デジタルデータレ コーダに記録した。記録データを基にパソコンなどを用いて 抗力係数、質量力俰数などの諸特性を解析した。

\section{4. 実験結果と考察}

4-1. 流九耐性

図ー7は定常流速值を段階的に上昇させた場合のエビの 最大遊泳速度の成長サイズによる变化を遊泳パターンとと もに示したものである。実験開始時、底面に定位していた エビは主流流速值の上昇で下流方向へ流され始めるととも に徐々に遊泳を開始し、エビの遊泳限界速度に近つくと頭 部を底面近傍に押しつけるようにして流水からの抵抗を極 力避けるような遊泳形状をとるようになり、限界值を越え ると次第に下流方向に流されはじめるようになる。流下が 始まる直前の流速值をエビの最大遊泳速度（usmax）とし て評価した上で、図ー7に示すように、従来より魚類の遊 泳能力の評価基準として用いられている体長比 (BL/sec)で 整理すると、ホッカイェビの最大遊泳速度の体長比は、体 長の增大とともに若干減少する傾向が慧められるが概して 体長の 3 倍程度の值に相当することがわかる。一般にエビ の害敵となる多くの魚類のそれが体長の約 10 倍であること と比較すれば本種が隀れ場である藻場内から一度流出して しまえば害敵の格好の䬣となりうることを示唆している。

\section{4-2. 流体力係数}

図一8はホッカイエビの正の走流遊泳に対する抗力係数 （CD）の、体長BLを代表長として計算されるレイノルズ 数 $(\mathrm{Re}=\mathrm{BL} \cdot \mathrm{ub} / \nu: \nu$ は流体の動粘性俰数) に上る変化 を示したものである。図ー7に示したェビの最大遊泳速度 に対応するレイノルズ数が最大でも20,000程度 (最大体長 時）以下であることを考虑すれば、遊泳時のエビに作用す る抗力の評価としての抗力俰数はレイノルズ数によって遷 移状態で推移し、定常流場、振動流場共に、

$$
C_{D}=2.16 \times 10^{4} \mathrm{Re}^{-0.84}
$$

で同一曲線状に近似できる。

図一 9 は質量力係数 $\left(\mathrm{C}_{\mathrm{M}}\right)$ の K. C. 数 $(\mathrm{K} . \mathrm{C} .=\mathrm{T} \cdot \mathrm{ub} /$ BL：Tは振動流の周期)による変化を示したものである。

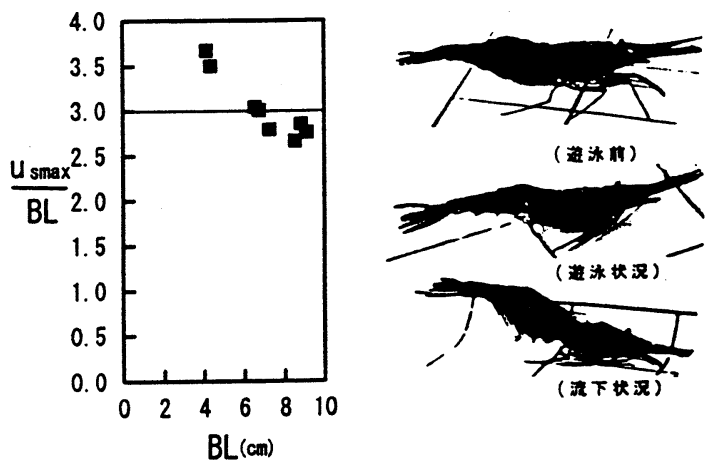

図一～最大遊泳速度及び遊泳パターン

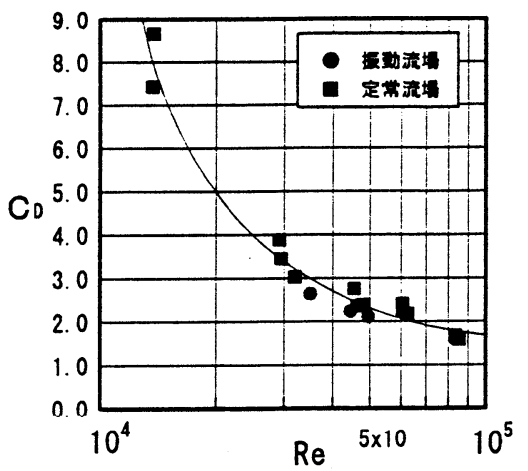

図ー8 抗力倸数のレイノルズ数による変化

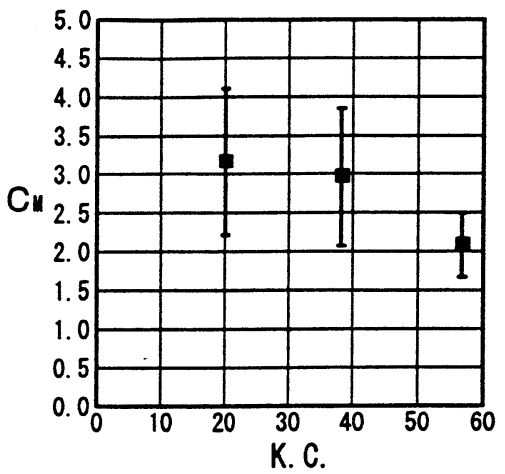

図ー9 質量力係数のK.C. 数による変化

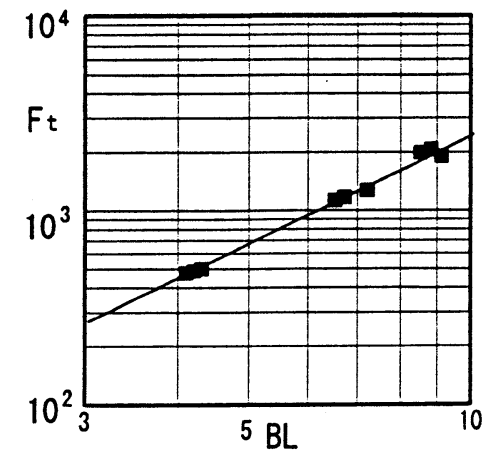

図ー10 最大推力の体長による変化 
エビに作用する流体力に占める質量力成分は抗力成分と比 較して小さいため、実験的に得られる $\mathrm{C}_{\mathrm{M}}$ 值は計測装置の 精度上の限界よりかなりのばらつきが瑟められるが大局的 には2〜3の間の值をとりながら、K.C.数の增加とともに 减少してゆく傾向が珰められる。

\section{4-3. 最大推力及び推進力}

図ー7及び図ー8の結果を基に(5)式よりホッカイエビ が最大遊泳速度で前進時の推力 $(\mathrm{Ft})$ 及び推進力 $(\mathrm{P})$ を成 長段階別に整理すると図ー10、図ー11となる。図に示すよ うに推力、推進力は何れも体長の累乗に比例し、各次式で 近似できる。

$$
\begin{aligned}
& F t=32.2 \mathrm{BL}^{1.9}(\mathrm{dyn}) \\
& \mathrm{P}=1.96 \times 10^{-5} \mathrm{BL}^{2.5}(\mathbb{W})
\end{aligned}
$$

\section{4-4.ホッカイエビ生息場造成条件}

一度、藻場外へ流出したホッカイエビが再び藻場内まで 遊泳・到達し藻場内で能動的に生息することが可能な流動 波浪条件を生息場造成のための必要条件と䒓えれは、（2）、 （3）、（5）、（6）、（7）式を（1）式に代入し、エビ自身の慣性力 は微小として無梘すると、エビの最大推力がエビに作用す る流体力を上回る条件として成長段階毎の生息場の許容流 動・波浪条件が導かれる。

図ー12は波浪場におけるエビ生息場として满足すべき許 容最大波高值 $(\mathrm{Hm})$ の波周期による変化を体長 $\mathrm{BL}=7 \mathrm{~cm}$ の場 合について生息域水深（d)別に示したものである。ここ に、（1）式における流速值は微小振幅波理論をもとにエビ が遊泳する水底面近傍における流速值として計算してい る。これより、許容最大波高値は周期の增大により水深毎 にほほ一定值に収束（抗力成分が卓越）することがわか る。この値を新たに許容波高値 ( H max) として再評価し た上で、その水染による变化を体長別に計算したものが図 ー13で、H maxは近似的に次式で表現できる。

$$
\mathrm{H} \max =3.47 \times 10^{-2} \mathrm{BL}^{0.8} \cdot \mathrm{d}^{0.5}
$$

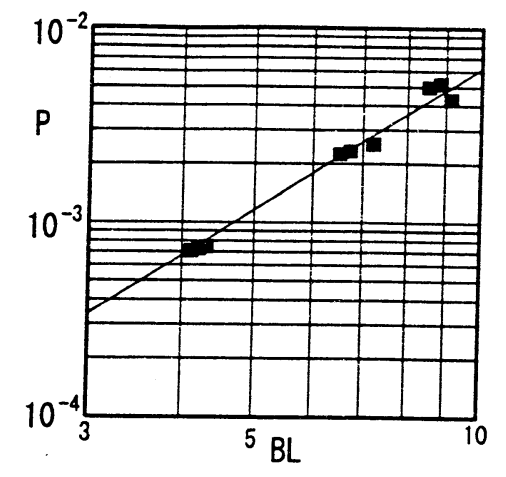

図一11最大推進力の体長による変化

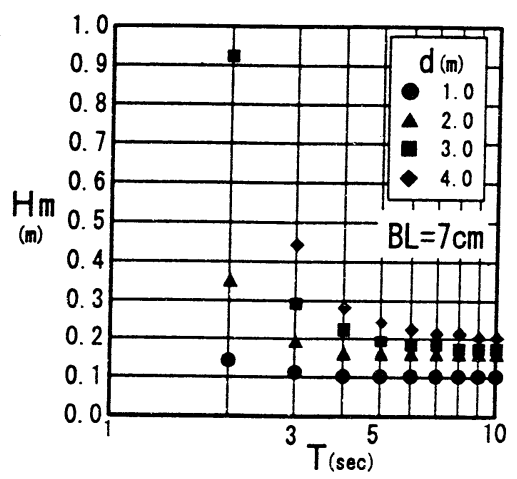

図-12 許容波高値の周期による変化例

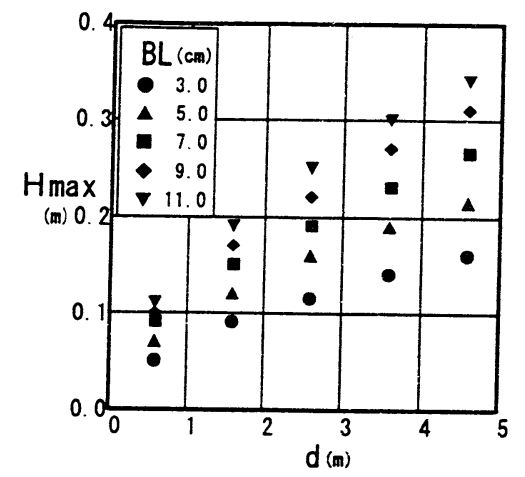

図-13 許容最大波高値の水媣による変化

従って、ホッカイエビ生息場（造成場）の水媣帯及び增殖・資源管理対象となるエビの成長サイズが決定され れば(9)式よりホッカイエビの生息場として満足しなければならない波浪の静稳条件が導かれる。

5.おわりに

ホッカイエビの生息を規定する棵境要因には、流動の他に餌生物や水温、塩分浱度など样々な複合要因が考え られるが、本研究では、薄場造成などにより人為的に制御し易い棵境要因として流動・波浪要因について検討し 一連の成果を得た。本成果を実祭の現場に適用するためには、アマモ場などの波浪減衰特性を評価する手法を開 発した上で、ホッカイェビ生息場として満足すべき藻場の繁猛度や藻場の造成幅等を藻場による波浪減衰特性 より決定する必要がある。

参考文献

1)柏木正章：山田湾産枋仕代の生態学的研究IIーエビの成長に伴う性の発達ならびにその転換について、日本 水産学会誌、Vol.40, No. 10,1974,pp986〜992.

2)水島敏博：野付湾本力仁比の成長に伴う分布と密度の変化, 北海道立水産試験場報告, Vol. 29, 1987, pp $25 \sim 35$.

3)水岛敏博：朷仕比の個体群構造の季節变化、北海道立水産試験場研究報告、Vol. 39, 1992, pp53〜63. 